\title{
Vinte ANOS De Educação Especial (GT15) NA ANPEd
}

Este é um Número Especial da Revista Brasileira de Educação Especial que traz um resgate sobre os 20 anos do Grupo de Trabalho (GT15) - Educação Especial, no âmbito da Associação Nacional de Pesquisa em Educação - ANPEd.

Em 1991, na 14 ${ }^{a}$ Reunião Anual da associação, a criação do grupo foi aprovada, (após funcionamento de dois anos como Grupo de Estudos) por unanimidade, pela assembleia. Foi reforçada, assim, a necessidade de haver um espaço específico para discussões da produção científica brasileira em Educação Especial nas reuniões anuais (RA) da ANPEd. O GT Educação Especial merece destaque pelo seu pioneirismo na congregação de profissionais e seu histórico de atuação, o qual poderá ser acessado pela leitura do artigo de abertura desta edição.

Na Reunião Anual da ANPEd, no ano de 2010, foi aprovada, pelo participantes do GT de Educação Especial, a proposta para este Número Especial. O objetivo desta edição da revista é mostrar o papel e a contribuição do GT para socialização da produção científica em Educação Especial. Ressalta-se a importância desta edição, comemorativa da consolidação da área em uma das mais importantes associações de pesquisa e pós-graduação da América Latina.

Em reunião do Comitê Editorial da Revista, em novembro de 2010, durante o Congresso Brasileiro de Educação Especial, ocorrido na Universidade Federal de São Carlos, a proposta foi aprovada.

A partir deentão, conjuntamente, o editor da revista e a atual Coordenadora da GT, Rita de Cássia Barbosa Paiva Magalhães, membro da Diretoria da ABPEE e do Comitê Editorial, procedeu-se aos preparativos para o convite a todos os excoordenadores do GT de Educação Especial. Nesse convite, foi formulada uma proposta para cada um dos autores dos artigos da revista, deixando a cargo de cada autor a possibilidade de convidar outros pesquisadores para auxiliar na preparação dos manuscritos.

Paralelamente à preparação do Número Especial, o editor da revista solicitou apoio financeira do $\mathrm{CNPq}$, proposta aceita e com recursos aprovados para o auxílio na publicação de todos os números do volume 17, referente a 2011.

O resultado desse empreendimento foi bastante gratificante, pois todos os convites foram aceitos e todos os manuscritos estão publicados. 
Os temas tratados no presente números se referem:

- $\quad$ aos primórdios da criação GT 15, Grupo de Trabalho da Educação Especial;

- a reflexão da pesquisa em Educação Especial e os valores humanos subjacentes a eles.

- aos produtos decorrentes da trabalhos de pesquisa apresentados no GT de Educação Especial da ANPEd nesses 20 anos;

- a política brasileira de Educação Especial e sua perspectiva inclusiva ;

- aos procedimentos e recursos de ensino em Educação Especial;

- a sala de recursos como serviço especializado;

- a formação de professores em Educação Especial;

- a Educação Especial na Educação do Campo;

- ao Estigma e currículo oculto.

Nota-se que os temas são atuais, polêmicos e ainda carecem de reflexão e empreendimento mostrando o fôlego com o qual o GT 15 chega aos 20 anos de idade. Como afirmam Ferreira e Bueno, além de reunir pesquisadores e profissionais, o GT vem se constituindo como espaço de confronto intelectual que possibilita a interlocução em torno das questões prementes da Educação Especial Brasileira. Isto fica explícito nos artigos aqui publicados.

Comitê Editorial Eduardo José Manzini Maria Cristina Marquezine Leila Regina d Oliveira de Paula Nunes Nerli Nonato Ribeiro Mori Rita de Cássia Barbosa Paiva Magalhães Eliza Dieko Oshiro Tanaka 